\title{
The intra-urban residential and workplace locations of small business owners
}

Dr Darja Reuschke

University of Southampton

School of Geography and Environmental Science

ORCID ID orcid.org/0000-0001-6961-1801

Prof Donald Houston

University of Portsmouth

School of the Environment, Geography and Geosciences

ORCID ID http://orcid.org/0000-0002-7178-9630

Contact: Darja Reuschke, University of Southampton, School of Geography and

Environmental Science, University Road, Southampton, SO17 1BJ, United Kingdom

Email: d.reuschke@soton.ac.uk

\section{Acknowledgement}

The data collection for this research was funded by an Early Career Grant from the Regional Studies Association to Darja Reuschke. Darja Reuschke's time working on this paper was funded by the WORKANDHOME Starting Grant from the European Research Council (ERC-StG-2014-639403). We are indebted to Martin Schäfer (University of Portsmouth) for the selection and extraction of bespoke commuting flows from the Census of Population and Paul Carter (University of Portsmouth) for creating the Edinburgh map. We are grateful to three anonymous reviewers for their valuable comments and suggestions.

\footnotetext{
Abstract

The notion that buzz, creativity, diversity, openness and a sense of bohemia in cities are important to attract creative workers and entrepreneurs has grown in prominence both in academic literatures and in city economic development strategies. However, there is a disjuncture in the literature and dearth of evidence as to whether entrepreneurs seek bohemian (open, diverse) places in which to live or to locate their business. This study explores the kinds of neighborhood small business owners, in particular entrepreneurial small business owners, live and work in, and the extent to which their intra-urban locational patterns diverge from the general working population. Survey data of small business owners in Edinburgh (UK) uniquely capturing both business location and the residential location of the business owner, and Census data covering all workers with workplaces in Edinburgh are used. Findings support the attraction of some entrepreneurs to bohemian neighborhoods both as places to live and as places to work. Equally, however, findings stress the importance of a diversity of neighborhood types, including attractive suburban neighborhoods, due to business cycle and personal life course effects making non-bohemian neighborhoods also attractive to small business owners.
} 


\section{Introduction}

The impact of small firms and entrepreneurship on urban success has attracted new attention in urban economic research (Glaeser et al., 2015, 2010a; Lee, 2017). Entrepreneurship and small businesses are seen as increasingly important drivers of employment and entrepreneurial growth (Acs \& Armington, 2004; Audretsch \& Keilback, 2004; Glaeser et al. 2010b; Lee, 2017; Yang Liu \& Huang, 2016). Accordingly, economic development has seen a shift from policies aimed at shaping the location of (large) firms towards attracting and nurturing new firms (Audretsch, 1998).

What features of the urban environment attract entrepreneurs and small business owners is therefore a timely question for urban policies across many countries. The notion that buzz, creativity, diversity, openness and a sense of bohemia in cities are important to attract and retain creative and innovate workers and entrepreneurs has grown in prominence both in academic literatures and in city economic development strategies (Evans, 2009). Creative capital theory argues that the returns to creativity (broadly defined, including creative workers, innovation and entrepreneurship) have increased as the economy has become more knowledge intensive, and that the new creative class, defined as workers who "create meaningful new forms" (Florida, 2003a, 8), are particularly attracted to bohemian places (Florida 2002, 2003a). This new emphasis on creativity follows the conceptualization of city economic success being derived from diversity (following Jacobs (1966)) rather than specialization (following Marshall (1925)).

When referring to innovative, diverse and tolerant places, Florida (2003a) refers to cities as well as neighborhoods and communities suggesting that not only cities attract people but also certain places within cities (although in his empirical work neighborhood- and city-level evidence is "muddled" (Shearmur, 2009, 380)). Florida (2003b) further sees artistic and cultural creativity (openness), economic creativity (entrepreneurship) and technological 
creativity (innovation) as interdependent and mutually reinforcing. Others have also argued in favor of neighborhood effects on entrepreneurship on the basis of externalities through social interactions within the neighborhood (Andersson \& Larsson, 2016). Subsequent studies investigating the seminal ideas of Florida (2002) have tended to focus on artistic and cultural creativity and whether creative workers are attracted by urban amenities versus jobs (e.g. Darchen \& Tremblay, 2010; Hansen \& Niedomysl, 2009; Houston et al., 2008; Miguélez \& Moreno, 2014; Sánchez-Moral et al., 2018), while the location choices of entrepreneurs have received much less attention. Despite creative capital theory assuming that creative people seek a certain residential environment (as much as, if not more than, a place to work), existing studies on the location choices of creative businesses and entrepreneurs have focused on the location of firms, similar to research on industry clusters (He et al., 2018; Heebels \&Van Aalst, 2010; Wenting et al., 2011).

This paper is the first (to the best of the authors' knowledge) to investigate both the residential and workplace/business environment of entrepreneurs and business owners within a city or metropolitan region. The paper compares the "bohemianness" of residential and workplace locations of a sample of entrepreneurs and business owners. This is important for two reasons. First, it helps reveal what features of urban environments are attractive to entrepreneurs. Second, it points to where (residential neighborhood vs commercial zone) and through what channels (personal vs business) knowledge spillovers and innovation may take place.

The paper explores empirically the intra-urban location choices of small business owners, in particular entrepreneurial small business owners, through the neighborhood characteristics and spatial patterns covering both the business (workplace) location and the residential location of the owner and resultant commuting patterns. Drawing on the creative class literature, we specifically explore whether small business owners are attracted to bohemian neighborhoods as a place to live and/or as a place for their businesses. Since the idea that diversity and 
openness is particularly important for creative, urbanite entrepreneurs (Florida, 2003b), our analysis further differentiates between entrepreneurial and non-entrepreneurial small businesses (Glaeser et al., 2010a) and explores whether entrepreneurial small business owners are more likely to live and/or have their businesses located in bohemian areas than less entrepreneurial small business owners. These questions form the specific research aims of this paper.

We use a primary sample of small businesses in the City of Edinburgh (United Kingdom) and compare these with all workers who work in Edinburgh in relation to neighborhood types and intra-urban spatial patterns. Taking the whole working population as a comparison group follows the key notion of the creative class literature that urban economic research should focus on people rather than firms (Florida et al., 2008). This methodology allows new insights into the distinctiveness (or not) of the types of neighborhood small business owners live and work in and into the role of "bohemian" neighborhoods for small business owners. Findings on whether small business owners seek bohemian neighborhoods where they live versus where their business is located are important for urban economic policy and urban planning in terms of where in the city interventions are needed or useful and the kind of strategies that may attract entrepreneurs.

We first discuss insights from the existing urban economic and small business literatures into the urban location of small businesses and the relationships between business owners' residential location and the location of their businesses. Connections are made between residential and business location in the creative class theory which we then assess and highlight what it predicts in terms of the location of urban small businesses. We then describe our primary and secondary data sources used to answer our research questions and our methodology to identify bohemian neighborhoods and entrepreneurial vs non-entrepreneurial businesses - key concepts in our research design. The subsequent presentation of our empirical 
findings is structured around our two research questions, whereby we first present results on where small business owners live and work compared with the whole workforce and, second, test whether entrepreneurial vs non-entrepreneurial small business owners in our survey data significantly differ in where they live and work. The concluding section critically discusses consequences of our empirical findings for future research and whether urban planners need to consider diverse bohemian residential neighborhoods or diverse bohemian workplace zones to deliver the creative buzz sought by entrepreneurs.

\section{Literature review}

\section{Trends in the urban location of small and new businesses}

The knowledge economy has created new production spaces within cities, often in the form of micro clusters of new economy industries in the inner city such as multimedia and software design, the arts and cultural sector and creative industries that have come to utilize new technologies in innovative and transformative ways such as architecture and advertising, often with diverse eco-systems of small businesses and freelancers (Evans, 2019; Foord, 2012; Hutton, 2004). This has reinvigorated the role of the Central Business District (CBD) and adjacent inner/central city areas as a place of production (Larsson, 2017). While old industries, manufacturing, distribution, and routine elements of the service sector, characterized by large firms, have over a long period moved out of inner-city areas into suburban and exurban locations, the increase of non-routine occupations that utilize "diverse cognitive and cultural capacities of workers" (Scott, 2011, 297) shows a strong tendency for CBD and central city locations (Larsson, 2017).

Despite this resurgence of the inner city as a production space in the knowledge/creative economy, recent business and creative industry studies have also drawn attention to the importance of residential environments for business location (Folmer, 2014). The small 
business sector (0-49 employees) shows a high prevalence of businesses in residential premises (home-based businesses) (Mason et al., 2011). Kane and Clark (2019) estimate for metropolitan areas in Southern California (USA) that one in six businesses are run from residential properties as opposed to commercial properties. Importantly, businesses run from residential properties are different from businesses run from commercial properties especially in that they are mostly located in predominantly residential areas (Kane \& Clark, 2019). In similar vein, Phelps (2012) underlines the importance of an increasingly diverse suburban economy. He describes suburban home-working business communities as part of both cosmopolitan suburbs (although he suggests these may be quantitatively few) and bourgeoise suburbs. These types of suburbs seem to accommodate creative and innovative businesses in film, television and video production in home offices as shown by Gornostaeva (2008) for London.

Thus, in summary, a complex spatial pattern of small businesses has emerged in cities and metropolitan areas with clusters of business activity in central areas and outside of these including in residential suburban areas.

\section{Influences of residential location on business location}

It has been longer recognized in the business and management literature that quality of life factors and residential preferences of employees and managers influence firm relocation and expansion, particularly in firms for which the attraction and retention of professional workers is a concern (Gottlieb, 1995; Love \& Crompton, 1999). More recently, business and entrepreneurship studies have argued that the residential preferences and personal life choices of the business owners themselves are important for understanding business location, in particular in which region or metropolitan area businesses are started. Underlying reasons for how residential location influences business location suggested in the literature include the 
value attached to quality of life and urban amenities (Curran et al., 2016; Johnson \& Rasker, 1995; Wenting et al., 2011); family and the embeddedness of business activity in social/local interactions (Dahl \& Sorenson, 2009; Larsson et al., 2017; Pallares-Barbera et al., 2004); social capital and information costs (Figueiredo et al., 2002) and labor markets (May et al., 2001). While quality of life features and urban amenities, such as an inspirational environment, social atmosphere and cultural amenities, have been used to explain why business start-ups are attracted to certain metropolitan areas (Curran et al., 2016; Wenting et al., 2011), the remaining factors (family, social capital, information costs and labor markets) have been used to explain why people remain in a region and start their businesses, for example where they studied, used to work or grew up (Dahl \& Sorenson, 2009; Michelacci \& Silva, 2007; Pallares-Barbera et al., 2004).

At the intra-urban scale, a range of factors have been suggested could be at play linking the business and residential locations of business owners, but empirical evidence is sparse. As in the case of businesses run from residential premises, often the nature of the business does simply not require commercial premises (Mason et al., 2011) and the business is started in the home as the space is available (Vorley \& Rogers, 2012). Some business owners also "live over the store" (Davis, 2012), either literally or where "live in" accommodation can be integrated to business premises, e.g. in small hotels and guest houses (Lynch, 2005).

Entrepreneurs and small business formation have featured in discussions and some empirical analysis on the renaissance of central urban living (Moss, 1997). Underlying reasons mentioned included the preference of working and living in the same place (neighborhood or work/live unit) and the affordability of desired living and working spaces (Allen, 2007; Goldberg-Miller \& Heimlich, 2017; Markusen, 2006; Moos, 1997) suggesting that small business owners and entrepreneurs may not only drive inner-city living but also inner-city working (Moos, 1997). These studies either focused on inner-city regeneration areas or creative people/artists, so it 
remains unclear whether these location preferences apply to entrepreneurs and small business owners more generally (or only to creative people/artists or those who live in certain centrallylocated neighborhoods).

\section{Creative Class Theory}

The residential preferences of some entrepreneurs and small business owners described in the above studies are similar to the bohemian environment that Florida (2002) suggested creative workers and entrepreneurs seek. While Florida (2002) measured bohemia in his groundbreaking paper simply as the concentration of creative occupations, a bohemian place is further described by Lee, Florida and Acs $(2004,883)$ as "open" and "intellectually dynamic" or more precisely as a place with high level of urban amenities (cafés, bars etc.), authenticity and aesthetic quality of the housing stock that promotes self-expression and idea generation (Florida \& Mellander, 2010). A bohemian neighborhood is thus defined by a mix of factors including socio-demographic and occupational characteristics of its inhabitants and housing stock.

Existing evidence suggests that entrepreneurs are attracted to cities and metropolitan areas with urban amenities and buzz (Wenting et al., 2011) but little evidence is available on their intraurban residential location choices. Florida and King (2017) found a concentration of some startups in urban dense neighborhoods suggesting that entrepreneurs seek dense, dynamic places to work which links to wider evidence in economic geography on the importance of face-to-face interaction and knowledge spillovers for innovation (McCann, 2008). While empirical work has not disentangled whether entrepreneurs are attracted to these places as places to work and/or live, there is the underlying assumption in the creative class theory that entrepreneurs seek bohemian places (intellectually dynamic and idea generating places) both as places to live and work. 
Studies on the residential location among creative workers (including employees) reveal heterogenous residential locations and preferences. Artists were found to be more likely to live in neighborhoods with high density, older housing stock, highly-educated residents and nonfamily households (Grodach et al., 2014) broadly supporting preferences for bohemian neighborhoods as places of high level of urban amenity and aesthetic (Florida \& Mellander, 2010). Empirical evidence for other occupational groups within the creative class (representing a more sizeable proportion of the workforce than just artists), however, rather suggests similar residential location preferences and commuting patterns to high-skilled and high-income households (Van Oort et al., 2003) with young creative workers living in the city center and those with families living in suburban areas (Lawton et al., 2013). Thus, at the intra-urban level, many creative workers still seem to follow common patterns of residential location driven by physical distance to work and/or the city center and access/space trade-off (Alonso, 1964; Muth, 1969) and social/housing status (Phe \& Wakely, 2000).

In conclusion, creative class theory suggests that entrepreneurs are attracted to bohemian neighborhoods. More indirectly, it is suggested that entrepreneurs seek bohemian neighborhoods as places for their businesses but also as places to live. From this we can further infer that non-entrepreneurial small business owners are less likely to live and work in bohemian neighborhoods as they are less dependent on a stimulating and idea generating environment and have residential preferences that align more with common patterns of residential location in the population.

\section{Research design, data and methods}

\section{City of Edinburgh case study}

The City of Edinburgh, Scotland, UK, was chosen as a case study for three reasons. First, it is representative of creative cities in terms of density of creative workers, cultural offer, creative 
milieu and quality of life. Second, it offers a range of neighborhood types from relatively bohemian to traditional making it an ideal city in which to examine the residential choices of small business owners in relation to these neighborhood types. Third, the city has a large and growing small business sector.

In terms of general economic context, Edinburgh's economy is based largely on the service sector, particularly financial and insurance services, which account for some $20 \%$ of the city's GVA, and $10 \%$ of the city's jobs, compared to only $5 \%$ of jobs in other UK cities (City of Edinburgh Council, 2018). Manufacturing has always been a very small sector in Edinburgh. Large sectors, although proportionately of a similar scale compared to other UK cities, are health ( $15 \%$ of jobs), professional and scientific services ( $9 \%$ of jobs) and education $(9 \%$ of jobs). Smaller sectors but representing larger shares of the city's employment than in other UK cities include arts, entertainment and leisure ( $6 \%$ of jobs) and information and communication (5\% of jobs). Following the Global Financial Crisis of 2008, the city has seen strong growth in its small business sector and the city authorities have continued to promote creative industries (City of Edinburgh Council, 2018).

On many measures, Edinburgh ranks highly on what might be considered quality of life, creativity and innovation. Historically, Edinburgh is known for its role in scientific discovery, philosophy and literature during the European Enlightenment (Buchanan, 2003), and still has three universities. The city hosts the Edinburgh Festival Fringe with an audience of 2.7 million in 2017, as well as a number of other large arts festivals (Edinburgh International Festival, Edinburgh International Book Festival, Edinburgh International Art Festival). Edinburgh is known internationally for the Georgian architecture and planning of its New Town, its medieval Old Town and ranks number three in the UK in terms of number of high-quality restaurants (City of Edinburgh Council, 2018). Migration, conceived by Florida (2002) as reflecting openness, also connects Edinburgh to international and national flows of human 
capital, with $15.9 \%$ of the city's population born outside the UK. ${ }^{i}$ As well as cultural offer and diversity, Florida argues deep labor pools for career progression are still relevant in attracting creative workers, and Edinburgh's labor market ranks close to the top of all UK cities in terms of employment rate $(75.6 \%$ of the working-age population in 2018$)$, earnings ( $£ 30,700$ per working resident, 2018) and proportion of high-skilled occupations (38.6\% of jobs) (City of Edinburgh Council, 2018).

Areas of the city that could be considered bohemian in terms of high level of urban amenities and aesthetics (Florida \& Mellander, 2010) include high-density studentified areas of traditional tenement-style apartments close to the city center, as well as diverse cosmopolitan areas including gentrified and regenerated areas. The city also contains affluent and suburban residential areas, so people have a choice between bohemian and traditional neighborhoods, which is important in relation to the suitability of Edinburgh as a case study of residential choice with reference to the creative class theory.

\section{Figure 1}

In relation to small businesses, Edinburgh is an appropriate case study as its population of small businesses is growing in size, particularly in high-skilled sectors. Small businesses (those with 0-49 employees) grew in number in the city by $20 \%$ between 2012 and 2015, almost double the growth rate for Scotland (11\%), and considerably greater than the growth rate in the number of medium-sized enterprises (50-249 employees) in Edinburgh (with 7\% growth) and large enterprises (250+ employees) in Edinburgh (with 2\% growth) (City of Edinburgh Council, 2018). Small businesses in Edinburgh are disproportionately found in the professional, scientific and technical services and the information and communication sectors (Edinburgh City Council, 2018) ${ }^{\mathrm{ii}}$. 
The city had 518,500 inhabitants in $2018^{\text {iii }}$, plus a hinterland of several small towns. Road and rail networks converge on the city's central business district, with the central railway station (Edinburgh Waverley) at its commercial, geographical and historic core (Figure 1).

\section{Research design and data}

Existing secondary business data do not capture the residential locations of business owners. In the UK, administrative business data also do not cover unregistered businesses or the majority of home-based businesses, i.e. businesses that form a significant part of the small business sector. ${ }^{\text {iv }}$ We therefore conducted a primary survey of small business owners using a standardized questionnaire.

Small establishments are differently defined in existing studies on urban growth and agglomeration according to the number of their employees (e.g. Lee, 2017; Rosenthal \& Strange, 2009). We follow Rosenthal and Strange's (2009) definition of small establishments and select firms for this study with less than ten employees as their study highlights the importance of this segment of businesses for urban economic success. Small businesses with 0-9 employees account for $97.6 \%$ of all private enterprises in Edinburgh. ${ }^{\mathrm{v}}$

We selected a random sample of businesses in Edinburgh using the commercial firm database ORBIS of the Bureau Van Dijk which includes unregistered and registered businesses through a mix of administrative business register and web search. Purchased firm records included the full postal address of the business as well as information about whether the firm is registered or not and categories for numbers of employees, allowing businesses with 0-9 employees to be identified. The sample was stratified by firms' registration status with 1,000 records of unregistered businesses and another 1,000 records of incorporated businesses.

The survey ran from December 2013 to February 2014. The questionnaire was sent by post to the business address. The questionnaire specified that the survey is addressed to the owner, 
director or any partner of this business. Of the 2,000 business records, 198 questionnaires were returned as undeliverable. A total of 185 completed questionnaires were returned which corresponds to a response rate of 10 per cent. Similar response rates are reported in other business surveys (e.g. Mason et al., 2011). The return was slightly higher among the registered businesses than the unregistered businesses (10.4\% vs. 9.5\%). In this study 153 businesses are included for which we have information on both the location of the business and the residence of the owner. The residential location was captured in the survey as postal code. The postal code of the business address was taken from the purchased firm records. ${ }^{\mathrm{vi}}$

Business owners were asked about the type of business premises they currently use on which basis businesses with the home as premises or base and those in commercial premises were identified. We asked for a description of the principal activity of the business from which we derived an industry classification ${ }^{\text {vii }}$ and a knowledge-intensive activity classification ${ }^{\text {viii }}$.

\section{Defining entrepreneurial small business owners}

Small business ownership includes a variety of degrees of entrepreneurship, ranging from the less entrepreneurial (e.g. business inheritance, necessity-driven startups) to more entrepreneurial (e.g. business opportunity and/or innovation-driven) (Glaeser et al., 2010a). Entrepreneurship is defined as "the discovery, evaluation, and exploitation of future goods and services" (Venkataraman (1997) cited in Eckhard \& Shane, 2003, 336). A common approach in business studies is to use new firm formation as a measure of entrepreneurship (Glaeser et al., 2010a).

Following existing business studies, we define businesses that are younger than 24 months as new businesses (see, for example, the United Kingdom Survey of Small- and Medium-Sized Enterprises' Finances ${ }^{\mathrm{ix}}$ ). In addition, we asked for motivations for having started or joined the business with a list of response items provided including "to take advantage of business 
opportunity". We use this response as a second measure of entrepreneurship since opportunities are a key feature of entrepreneurship studies (Eckhard \& Shane, 2003). Other motivations included: to be my own boss, to pursue a passion/hobby, to work from home or close to home, to work flexible hours, could not find adequate employment. In the empirical analysis, we use both measures separately and combine these to indicate whether a business is entrepreneurial or not.

\section{Comparison of sampled business owners with all workers in Edinburgh}

For comparing the surveyed business owners' residential and workplace locations with the general workforce, we use the 2011 Census of Population which provides unique information on both the residential locations and the workplace locations of the whole population. Since our sampling frame for the business survey was business addresses (i.e. workplaces) in Edinburgh we select as comparison group the workplace population (rather than the residential population) of the City of Edinburgh.

We define bohemian neighborhoods using the 2011 Area Classification of the UK Office for National Statistics (ONS) for 'Data Zones'x. Census Data Zones are the smallest geographic unit available for Population of Census data typically encompassing between 500 and 1,000 people, so are geographically very small in cities and capture fine-grained neighborhood differentiation. This classification identifies two types of cosmopolitan neighborhood ("cosmopolitan student neighborhoods" and "inner city cosmopolitan"), which we use as the closest available proxies for Florida's concept of bohemian neighborhoods, i.e. neighborhoods with high level of urban amenities, authenticity and urban aesthetic (see section 2.3). The Area Classification is based on established geodemographic techniques and uses compound measures of economic, social, demographic and built environment characteristics of small areas (see Gale et al., 2016) rather than simplistic single measures (e.g. percent in certain 
occupational or social categories) thus reflecting in relation to the concept of bohemian places/neighborhood that a mix of factors relating to the inhabitants and the housing stock is relevant (see section 2.3). ${ }^{\mathrm{xi}}$ The ONS Area Classification has been used in population, health and transport research (e.g. Dennett \& Stillwell, 2010). We do not include the ONS Area Classification's ethnically diverse categories in our definition of bohemian on the basis that these neighborhoods do not necessarily include the aspects of creativity and openness inherent in the concept of "bohemia" (Florida 2002, 2003b; Lee et al., 2004) but rather some relatively traditional ethnic-minority communities linked to historic low-skilled immigration.

Figure 2

At Data Zone level, 24 types of neighborhoods are differentiated (that cluster into eight "super groups"). We adapt the ONS's aggregation of groups slightly in our analysis to reflect, firstly, our focus on "bohemian" and, secondly, the prevalence of particular neighborhood types in

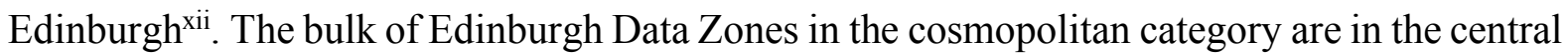
part of the city within $2 \mathrm{~km}$ of the city center ${ }^{\text {xiii }}$ (Figure 2) although also extending in a contiguous band to the west and northeast of central Edinburgh, with smaller pockets across the city. Affluent suburban areas often appear in a zone immediately beyond central Edinburgh, representing early bourgeois suburbs, giving way towards the edge of the city to a mosaic of comfortable suburbs, hard-pressed communities (including social housing estates) and pockets of manual workers in the "industrious communities" category.

\section{Association between entrepreneurial small businesses and cosmopolitan neighborhoods}

For answering the research question, whether entrepreneurial small business owners are more attracted than non-entrepreneurial small business owners to live and/or work in bohemian 
neighborhoods, we use binary logistic regression models on our primary survey data and the definition of cosmopolitan neighborhood from the ONS Area Classification (section 3.4).

Small study samples can overestimate (underestimate) the effect sizes (Odds Ratios) in logistic regressions (Nemes et al., 2009). We follow the "rule of 10" (Peduzzi et al., 1996) according to which one predictor variable can be studied for every ten events, and do not use continuous predictor variables (Vittinghof $\&$ McCulloch, 2006). On this basis, we present models with six predictor variables for the model estimating the likelihood of living in a cosmopolitan neighborhood and five predictor models for the models estimating whether business owners work in cosmopolitan neighborhoods. ${ }^{\text {iiv }}$

Our key predictor variable in these models is whether the business classifies as entrepreneurial or not (section 3.3). Because unregistered businesses are difficult-to-reach and had a slightly lower response rate in our survey than registered businesses (section 3.2), we conducted robustness checks for all models using a dummy indicating whether the business is registered or unregistered. We further included in separate models a control dummy for running a business as sole proprietor compared to all other legal states combined. We have not directly measured multiple ownership but used sole proprietorship as another dummy variable to proxy for single ownership since multiple versus single ownership may have an impact on business location. All of these variables were not significant in the models and also did not change the presented findings (robustness checks are not shown due to brevity).

\section{Description of survey sample}

Table 1 presents a description of the sample and survey variables. One-quarter of the sample are sole proprietors with the majority of owners running limited liability companies. The businesses employ on average 2.3 staff but just above one-third of the businesses do not employ any staff, i.e. consist solely of the owner. The average age of the businesses is 12 years while 
$11 \%$ are business startups $(<24$ months old). To put these numbers into context, of all businesses in the UK in $2014,76 \%$ had no employees (BIS, 2014). The business birth rate in 2014 was $13.7 \%$ in the UK and $12.7 \%$ in Scotland (ONS, 2015) which is slightly higher than in our sample but the UK Small Business Survey 2014, which is better suited for comparison with our sample, reported 5\% businesses younger than two years for non-employing businesses and $8 \%$ for employer Small- and Medium-Sized Enterprises (SMEs) (with 1-249 employees) (BIS, 2015a, 8). The businesses in our sample also appear to be younger than SMEs in the UK Small Business Survey 2014 across the whole age distribution.

\section{Table 1}

The level of entrepreneurship is high with just above half of the sample being either a new business or have been started (joined) by the owner because of seizing a business opportunity. In comparison, necessity is relatively small in our sample, as measured by a lack of jobs $(16 \%)$ generally reflecting Edinburgh's well-off service economy.

The largest share of business activity in our sample is in professional, scientific and technical services $(24 \%)$, financial services and real estate (16\%), followed by wholesale/retail $(10 \%)$ and food and accommodation services (10\%) reflecting well the Edinburgh economy (section 4.1). Overall, more than half of the sample (58\%) classifies as knowledge-intensive business activity (see endnote xiii).

In terms of type of business premises, we distinguish between businesses in commercial premises, with the home as premises (where the business is run from the own home) and the home as base (where most of the activity is performed outside the home). Compared with Mason et al.'s $(2011,631)$ small business study that reported 32\% home-based businesses (including home as a base) in urban areas in the UK, our sample contains proportionately more 
businesses with the owner's home as premises or base (together 47\%). This could be because we asked more specifically about working from no fixed premises or renting desk space, we only sampled businesses with less than ten employees, and the smallness of the manufacturing sector (which is less feasible to run from home) in Edinburgh. Interestingly, the proportion of businesses that classify as knowledge-intensive is highest in this sample amongst businesses that are primarily run from the owners' home and lowest amongst those run from commercial premises $(76 \%$ vs. $44 \%)$.

The demographic profile of the business owners is skewed towards men and older workers. The proportion of $24 \%$ women-led businesses in our sample seems to be in line with the national average of 20\% in SMEs (with 0-249 employees) in the UK in 2014 (BIS, 2015b). Only few business owners are younger than 30 years in the study sample reflecting that people tend to startup businesses when they are older and more experienced (Parker, 2004, 70-72). Those who started a new business in this study also seem to be older than the working population, mostly between 50-59 years old, while the existing literature often found that people 35-44 years of age are most likely to startup a business (ibid.). Our "opportunity" measure of entrepreneurship, to contrast, is more in line with established age figures with the highest proportion of opportunity-driven startup motivations stated by those between 30-39 years old (56\% compared with $49 \%$ and $41 \%$ among 50-59 and $60+$ year-olds respectively). In summary, compared to national business estimates our sample seems to contain more younger businesses and more larger businesses within the small business segment with less than ten employees. The demographic composition of the business owners, to contrast, confirms expected differences to the working population (more men, older workers, less often in single households). 


\section{Empirical Findings}

\section{Neighborhood types of locations of business owners and all workers}

Looking first at residential locations (Table 2), a much lower proportion of business owners live in poorer neighborhoods ("hard-pressed communities") and working-class neighborhoods ("industrious communities") while a much higher proportion lives in affluent suburbs compared to all workers in Edinburgh. It is not only that business owners more often than the general workforce live in "suburban-esque" areas in Edinburgh, but they live in affluent rather than "comfortable" suburban areas. Together this suggests a wealth distribution, similarly to Kane and Clark (2019) who found a concentration of businesses that are registered at residential premises in wealthier neighborhoods in Southern California. While entrepreneurial and non-entrepreneurial business owners are very similar in their preference for affluent suburbia, entrepreneurial business owners show a greater tendency than both all workers in Edinburgh and non-entrepreneurial business owners to live in cosmopolitan neighborhoods. Non-entrepreneurial business owners are remarkably similar in the extent to which they live in cosmopolitan neighborhoods compared with the general working population in Edinburgh.

Table 2

Entrepreneurial small business owners do not differ from the working population in their attraction to residential neighborhoods of highly qualified professionals but are less likely to live in ethnically and culturally diverse neighborhoods. Other studies also found that the creative class including the core of the creative class (artists) do not actually live in ethnically diverse neighborhoods (Bereitschaft \& Cammack, 2015; Grodach et al., 2014).

Taken together, the residential locations of non-entrepreneurial business owners broadly show middle-class residential preferences whereas the entrepreneurial business owners reveal a 
greater diversity, partly confirming the creative capital theory through living in cosmopolitan neighborhoods, partly opposing it through living in affluent suburban areas.

\section{Table 3}

Turning now to workplaces rather than residences (Table 3), just over half (52\%) of all workplaces in Edinburgh, but a substantially greater proportion (75\%) of entrepreneurial businesses are located in cosmopolitan neighborhoods. In contrast, the proportion of nonentrepreneurial businesses in cosmopolitan neighborhoods are similar to that of all workers (55\% versus $52 \%)$. Non-entrepreneurial business owners also more often than both entrepreneurial business owners and all workers work in neighborhoods with high concentrations of highly qualified professionals. Business owners, regardless of whether entrepreneurial or non-entrepreneurial, show a low tendency to work in ethnically and culturally diverse neighborhoods. As with residential locations, business owners are more likely than all workers to work in affluent suburban neighborhoods although the proportion is low compared with cosmopolitan neighborhoods.

Cosmopolitan neighborhoods in Edinburgh are concentrated in the center but stretch across outer areas (Figure 2). We therefore further explore the spatial patterns of residence and workplace locations among business owners in our sample and the whole of Edinburgh's workforce to better understand the extent to which small business owners, and entrepreneurial business owners in particular, diverge from common locational patterns. Table 4 shows the location of the residences and the workplaces of the sampled business owners and all workers with workplaces in Edinburgh according to three spatial zones: two zones within Edinburgh ("central" and "outer") and one zone outside of Edinburgh. ${ }^{\mathrm{xv}}$ The "outside zone" indicates the level of "in-commuting" into Edinburgh (from outside of Edinburgh) as all businesses in the 
sample and the comparison group of workers' workplaces are located within Edinburgh according to our sample frame. Similar intra-urban location classifications are commonly used in the urban economic literature (for example, Florida \& King, 2018; Florida et al., 2016; Frenckel et al., 2013 and Lawton et al., 2013 use a binary distinction of urban/core and suburban/outer). Although concentric urban models are rather simplistic given the complexity in the real world, the data presented in Table 4 add to the neighborhood analysis insights into the concentration versus deconcentration of workplaces (business locations) and residences.

\section{Table 4}

Entrepreneurial business owners also more often live and work in central areas of Edinburgh compared to both non-entrepreneurial business owners and all workers in Edinburgh. In Table 4, those who live and work centrally (second row) are a sub-group of those who live centrally (first row). Strikingly, almost all entrepreneurial business owners who live in central Edinburgh also work there (90\%). Non-entrepreneurial business owners are fairly similar to all workers in their preference for central areas as a place to live with the expectation that those who live in central Edinburgh also more often work there. Instead, non-entrepreneurial business owners show a great preference for living in outer Edinburgh compared to both all workers and entrepreneurial business owners, and further importantly, they tend to both live and work in outer Edinburgh to a much greater extent. Business owners, both entrepreneurial and not entrepreneurial, differ from all workers in their tendency to live within Edinburgh while incommuting from outside Edinburgh is much lower than among all workers. ${ }^{\text {xvi }}$

We further investigate the proximity of workplace and residential location that emerged in Table 4 among business owners, via commute distances. We calculated the commuting distance in a consistent fashion as straight-line distances. ${ }^{x v i i}$ For comparing the commuting 
distances between business owners in our sample, we select commuters in the 2011 Census of Population with workplaces in the same Census Data Zones in which the sampled businesses were located, on the basis that some parts of the city may attract longer or shorter commutes due to differences in accessibility (Hu \& Schneider, 2017; Shearmur, 2006). This comparison is the best proxy given the lack of city-level transport survey data for years after 2011.

\section{Table 5}

As shown in Table 5, very short commutes are much more prevalent among business owners. Of those with a commute to a fixed workplace (excluding business owners with the home as premises or base), almost one-in-five has business premises within a kilometer of their home and almost half within three kilometers of their home. For comparison, of all workers with jobs in the same parts of Edinburgh as the surveyed business owners' workplaces, only $6 \%$ lived within a kilometer and just below one-third within three kilometers of their workplace. ${ }^{\text {xvii }}$ The proportion of very small commutes of less than one kilometer is higher amongst nonentrepreneurial business owners to entrepreneurial business owners in our sample $(26 \%$ vs. $12 \%)$. However, the distribution of their commutes is fairly similar between $1 \mathrm{~km}$ and $5 \mathrm{~km}$ and statistically not significantly different at the mean.

Taken together, entrepreneurial small business owners are attracted to cosmopolitan neighborhoods to a great extent both at the residential and the work location although more entrepreneurs work than live in cosmopolitan neighborhoods. The extent to which they work and live in central areas is further striking adding to observations for creatives/artists (Markusen, 2006). In contrast, non-entrepreneurial small business owners are not more attracted to cosmopolitan neighborhoods as a place to live or work than workers on aggregate. However, affluent suburban neighborhoods are also important locations for the residences, and 
to a somewhat lesser extent workplaces, of both entrepreneurial and non-entrepreneurial small business owners, similar to existing studies that stressed suburban preferences among creative workers (Frenckel et al., 2013; Lawton et al., 2013), although our analysis reveals that entrepreneurial and non-entrepreneurial small business owners avoid long commutes, even if they live outside Edinburgh.

\section{Multivariate analysis of business owners' location in cosmopolitan neighborhoods}

This section further explores the factors associated with living and/or working in cosmopolitan neighborhoods of business owners using our primary survey and multivariate methods. Specifically, we test whether entrepreneurial business owners are more likely to work and/or live in cosmopolitan neighborhoods than non-entrepreneurial business owners. We start with cosmopolitan neighborhoods as a place to live. In Table 6, the dependent variable is One if the business owners live in cosmopolitan neighborhoods, or Zero if otherwise. Odds Ratios are displayed that indicate the odds of a one-unit change in the independent variable being associated with a different outcome in the dependent variable. To ease interpretation, we also report probabilities in the text. ${ }^{\mathrm{xix}}$

All three derived measures of an entrepreneurial business (startup, opportunity-driven and combined measure, see section 3.3) are included in the models. We further add a derived measure indicating whether the business activity is knowledge-intensive or not (see section 3.2 and endnote xiii) as these business activities may be more dependent on buzz and density (Storper \& Venables, 2004). Alternatively, we used a dummy indicating business services ${ }^{\mathrm{xx}}$ instead of knowledge-intensive activities. Findings are similar and only models with a dummy for knowledge-intensive activities are reported. As business characteristics, we further include the number of staff employed in the business (including none as reference category). 
We derive the variable "commute type" that includes whether the business is run from the home (i.e. zero commutes) or the home is used as a base to explore whether living or working in cosmopolitan neighborhoods is related to close proximity between business and home. The business owners in this sample have overall much shorter commutes than the working population (section 4.1) and $2 \mathrm{~km}$ is used as threshold to distinguish shorter versus longer commutes among the sampled business owners (see Table 5).

Socio-demographic characteristics of the owner (sex, dependent child in household and age) are included in the models to account for interrelated life course and lifestyle effects on residential location choices (Smith \& Olaru, 2013), in particular moves of families from city to suburban locations in order to improve housing and neighborhood quality (Clark et al., 2006).

\section{Table 6}

Findings in Table 6 provide some support for the attraction of entrepreneurial business owners to cosmopolitan neighborhoods as a place to live. Opportunity startup motivations and the combined measure of entrepreneurial business (opportunity-driven and startup) significantly increase the odds of living in a cosmopolitan neighborhood but not a young business (business startup) on its own. The confidence intervals for the estimates are rather wide due to our small sample although we can be $95 \%$ sure that the probability that an opportunity-driven small business owner lives in a cosmopolitan neighborhood in Edinburgh is between $51 \%$ and $84 \%$ - this compares with the $29.5 \%$ of all workers with workplaces in Edinburgh living in a cosmopolitan neighborhood (Table 2). Despite the association between opportunity-driven business owners and cosmopolitan neighborhoods as a place to live, we cannot find an association between knowledge-intensive activities and living in cosmopolitan neighborhoods 
(Model 4 in Table 6). Instead we find a positive association of non-employing business owners and cosmopolitan neighborhoods as a place to live. Together these findings suggest that cosmopolitan neighborhoods may be attractive as residential areas for small business owners at a stage where they seek to develop/grow their businesses (regardless of whether the business is knowledge-intensive or not).

Short commutes of less than $2 \mathrm{~km}$ are further connected with living in cosmopolitan neighborhoods of small business owners. Business owners who run their business from home, who by definition have no commute, are less likely to be found in cosmopolitan neighborhoods (see also Table 7), in line with previous studies that showed their suburban orientation compared to businesses in commercial premises (Kane \& Clark, 2019). The odds of living in cosmopolitan neighborhoods are decreased by $80-87 \%$ for business owners who run their business from home (and 94-95\% for business owners with no fixed commute). Cosmopolitan living is therefore in our study of small business owners not associated with the work/live unit as described in existing studies for artists (Markusen, 2006) but with having the business closeby which could be related to lifestyle but also business demands or family demands (long working hours, time pressure). Business owners who live in cosmopolitan neighborhoods and have short commutes of less than $2 \mathrm{~km}$ comprise in our sample architectural and planning services, medical practices and food and retail shops.

Personal life course influences on residential location show up in the age of the business owner. In Model 4 in Table 6 (not controlled for an entrepreneurial versus non-entrepreneurial business), the odds of living in a cosmopolitan neighborhood are decreased by $64 \%$ for those business owners 50 years and older. Sex and household composition of the owner are both not significant in the residential models.

Table 7 
Models in Table 7 investigate whether small business owners work in a cosmopolitan neighborhood (coded One) or outside of cosmopolitan areas (coded Zero). These models include business owners in commercial premises and those who run their business from home but exclude those with the home as base since for them we cannot define a workplace location. The same modelling framework is applied as in Table 6. Coefficients for a startup business, however, cannot be estimated in Table 7 (almost all startup businesses are located in cosmopolitan neighborhoods!). Further, models are displayed without the child co-variate. The variable had no effect and did not change other estimates (see section 3.5).

Estimates in Table 7 show strong support for the location of entrepreneurial businesses in cosmopolitan neighborhoods (Florida \& King, 2018). The odds of having the business in a cosmopolitan neighborhood are 2.5 and 3.7 greater for the opportunity measure and the combined startup and opportunity measure respectively (Models 1 and 3). In addition, almost all startups in this sample are located in cosmopolitan neighborhoods (88\%). To contrast, neither the knowledge-intensity of the business nor the number of staff employed in the business show associations with cosmopolitan neighborhoods as a place to work.

The connection between cosmopolitan neighborhoods as a place of work and commute distance is not significant. The Odds Ratios are still well below One meaning that some business owners commute into cosmopolitan areas. Lastly, none of the socio-demographic characteristics of the owner is associated with the location of small businesses in cosmopolitan neighborhoods.

In summary, an entrepreneurial small business as opposed to a non-entrepreneurial small business is associated with a cosmopolitan neighborhood in terms of both the residential and workplace location of the owner. Home-based businesses or the work/live unit are less likely to be found in cosmopolitan neighborhoods. Surprisingly, the number of staff employed in the business, generally used as a business performance indicator, is associated with the residential 
location of the business owner in a cosmopolitan neighborhood but not with the location of the business in a cosmopolitan neighborhood. We find socio-demographic characteristics of the owner to be important only for the residential location in a cosmopolitan neighborhood but not the workplace (i.e. business) location.

\section{Discussion and Conclusion}

The analysis presented in this paper provides support for the attraction of entrepreneurial small business owners to cosmopolitan neighborhoods at the intra-urban scale both as places to live and as places to work. This is coupled with an increased extent of working and living in urban central areas. However, non-entrepreneurial small business owners are remarkably similar in their probability to live or work in cosmopolitan neighborhoods to the general working population, and the vast majority lives and works in outer areas. These findings provide some support to the notion of buzz, creativity, diversity and openness as being important to attract and promote entrepreneurship in cities. However, the strong emphasis on the importance of bohemian urban neighborhoods in the creative capital theory still appears overstated for even entrepreneurial small business owners. This is, firstly, because entrepreneurial business owners are also attracted to mainstream and traditional affluent suburban neighborhoods, which in Edinburgh represent the older bourgeois suburbanization phase in the city in relative proximity to the city center and with good infrastructure in terms of transport and facilities - i.e. typical and ubiquitous aspects of location choice. Suburbs that offer a high degree of urban amenities are therefore also important for urban entrepreneurial creativity, as is supported by the earlier study by Gornostaeva (2008) for film, television and video production in London.

Secondly, life course factors are still linked to the residential locations of small business owners, with older business owners being more likely to live in the suburbs. Similarly, other 
studies found traditional age-related patterns of residential locations among creative workers little different to the general population (Lawton et al., 2013; van Oort et al., 2003).

Thirdly, the majority of entrepreneurial small business owners still lives in outer areas of Edinburgh and not in central parts, which is partly the result of cosmopolitan neighborhoods stretching into outer areas of the city. Together with their preference for affluent suburbs, these findings more broadly underline the notion of a diverse suburban economy and that in particular both cosmopolitan and bourgeois suburbs contribute to creativity as suggested by Phelps (2012).

While suburban urban amenities may play a role in attracting and retaining small business entrepreneurs to a city overall (Wenting et al., 2011), there may nevertheless also be some gains to be had from planners fostering bohemian residential neighborhoods (at least from the point of view of encouraging entrepreneurship). City planners might, however, be advised to facilitate and promote dense and diverse business communities in both residential properties and in commercial premises in central urban areas in order to help foster entrepreneurial business startups. In our case, cosmopolitan neighborhoods were strongly overlaid with high proportions of students and significant parts of cosmopolitan living were in outer areas, both of which are likely to reflect a preference for cheaper house prices which other studies have shown to be important for entrepreneurs ( $\mathrm{Li} \& \mathrm{Wu}, 2014$ ). Therefore, as businesses grow and evolve over the business cycle and their owners age and move through their life course, there is a need, as our findings suggest, for attractive suburban residences and a diversity of business premises and locations, including in suburban areas. A first key conclusion therefore is that the urban environment most likely to support entrepreneurship and small business growth is one characterized by a diversity of types of residential neighborhoods and commercial areas. Our findings further suggest that the proximity between home and workplace of small business owners (both entrepreneurial and non-entrepreneurial) is strikingly different to the general 
working population, with small business owners having remarkably short commutes. From this we draw the second key conclusion that an urban environment with residential neighborhoods and commercial areas in relatively close proximity to each other and/or with good transport connections between them is important for urban success.

The emerging literature on the influence of residential location and life choices of entrepreneurs on business location has employed different concepts for explaining why people tend to start businesses close to where they live or their family lives including social embeddedness, regional identity and social capital (Dahl \& Sorenson, 2009; Figueiredo et al., 2002; Pallares-Barbera et al., 2004). The much shorter commutes of business owners compared with the working population revealed in this study adds to this discussion a new dimension. Rather than long established relations and feelings about a place, we suggest for future research to investigate the daily time-space geography of business owner. Coupling constraints (Hägerstrand, 1970) may be one reason why small business owners work so close to home related to long working hours and time pressure. Alternatively, rather than constraints, business owners may simply have greater opportunities where to locate their business as argued by van Ommeren and van der Straaten (2008) in relation to the self-employed. The time geography framework seems fruitful for exploring further the commuting patterns of small business owners and why they are so short as revealed in our study.

Our research design has made a novel distinction between the residential and workplace location of business owners, utilized a representative sample of small business owners including unregistered businesses in Edinburgh and compared these to all workers in Edinburgh with comprehensive Census of Population data. However, using cross-sectional data means that directions of causality can only be inferred (as is the case with much work that investigates spatial patterns at a point in time). Nevertheless, our explorative analysis has provided convincing new evidence for understanding economic creativity not only through 
business location and industry cluster but also through residential location. Understanding the residential and business/workplace locations and preferences of entrepreneurial small business owners in particular is important in contextualizing claims of the importance of buzz, creativity, diversity and openness as being important to attract and promote entrepreneurship in cities and in helping urban planners shape cities conducive to entrepreneurship and economic growth. Cities require an eco-system of diverse neighborhoods to match a similarly diverse eco-system of entrepreneurs and small business owners as they and their business evolve through the business cycle and owners' life courses. Some entrepreneurs may be bohemian, but may nevertheless, as much as their bourgeois counterparts, prefer to live or locate their business in a traditional suburb with good access to transport, schools and urban amenities.

\section{References}

Acs, Z., \& Armington, C. (2004). Employment Growth and Entrepreneurial Activity in Cities. Regional Studies, 38(8), 911-927.

Allen, C. (2007). Of urban entrepreneurs or 24-hour party people? City-centre living in Manchester, England. Environment and Planning A 39, 666-683.

Alonso, W. (1964). Location and Land Use. Cambridge, MA: Harvard University Press.

Andersson, M., \& Larsson, J.P. (2016). Local entrepreneurship clusters in cities. Journal of Economic Geography, 16, 39-66.

Audretsch, D.B. (1998). Agglomeration and the location of innovative activity. Oxford Review of Economic Policy, 14(2), 18-29.

Audretsch, D.B., \& Keilbach, M. (2004). Entrepreneurship capital and economic performance. Regional Studies, 38(8), 949-959.

Bereitschaft, B., \& Cammack, R (2015). Neighbourhood diversity and the creative class in Chicago. Applied Geography, 63, 166-183.

BIS - Department for Business, Innovation and Skills (2014). Business Population Estimates for the UK and Regions 2014. BIS: London.

BIS - Department for Business, Innovation and Skills (2015a). Small Business Survey 2014: Businesses with no employees. BIS Research Paper Number 225. BIS: London.

BIS - Department for Business, Innovation and Skills (2015b). Contribution of women-led and MEG-led businesses to the UK non-financial economy. BIS (URN: BIS/15/542)

BIS - Department for Business, Innovation and Skills (2016). Longitudinal Small Business Survey Year 1 (2015): Businesses with no employees. BIS Research Paper Number 290. BIS: London.

Buchanan, J. (2003). Crowded with Genius: The Scottish Enlightenment: Edinburgh's Moment of the Mind. New York, HarperCollins.

City of Edinburgh Council (2018). Edinburgh by Numbers 2018, http://www.edinburgh.gov.uk/downloads/file/9904/edinburgh_by_numbers_2018 (accessed on 05.09.2019) 
Clark, W., Deurloo, M., \& Dieleman, F. (2006). Residential Mobility and Neighbourhood Outcomes. Housing Studies, 21(3), 323-342.

Curran, D. Lynn, T., \& O'Gorman, C. (2016). The Role of Personal Factors in the Location Decision of Software Services Start-up Firms. European Planning Studies, 24(3), 551567.

Dahl, M.S., \& Sorenson, O. (2009). The embedded entrepreneur. European Management Review, 6, 172-181.

Darchen, S., \& Tremblay, D.-G. (2010). What attracts and retains knowledge workers/students: The quality of place or career opportunities? The cases of Montreal and Ottawa. Cities, $27,225-233$.

Davis, H. (2012). Living over the store. Routledge: Milton Park and New York.

Dennett, A., \& Stillwell, J. (2010). Internal Migration in Britain, 2000-01, Examined Through an Area Classification Framework. Population, Space and Place, 16, 517-538.

Eckhard, J.T., \& Shane, S.A. (2003). Opportunities and Entrepreneurship. Journal of Management, 29(3), 333-349.

Evans, (2019). Emergence of a digital cluster in east London: birth of a new hybrid firm. Competitiveness Review: An International Business Journal, 29(3), 253-266.

Evans, G.L. (2009). Creative Cities, Creative Spaces and Urban Policies. Urban Studies, 46(5\&6), 1003-1040.

Figueiredo, O., Guimarães, P., \& Woodward, D. (2002). Home-field advantage: location decisions of Portuguese entrepreneurs. Journal of Urban Economics, 52, 341-361.

Florida R., \& Mellander, C. (2010). There goes the metro: how and why bohemians, artists and gays affect regional housing values. Journal of Economic Geography, 10, 167-188

Florida R., Mellander C., \& Stolarick, K. (2008). Inside the black box of regional development. Journal of Economic Geography, 8,615-649.

Florida R., Mellander C., \& Stolarick, K. (2016). Human capital in cities and suburbs. Ann Reg Sci, 57, 91-123.

Florida, R. (2002). Bohemia and economic geography. Journal of Economic Geography, 2(1), $55-71$.

Florida, R. (2003a). Cities and the Creative Class. City and Community, 2(1), 3-19.

Florida, R. (2003b). Entrepreneurship, Creativity and Regional Economic Growth. In: Hart, D.M. (ed.) The Emergence of Entrepreneurship Policy. Governance, Start-Ups and Growth in the US Knowledge Economy (pp. 39-59). Cambridge et al.: Cambridge University Press.

Florida, R., \& King, K.M. (2018). Urban Start-up Districts: Mapping Venture Capital and Startup Activity Across ZIP Codes. Economic Development Quarterly, 32(2), 99-118.

Folmer, E. (2014). Entrepreneurship in the neighbourhood: shifting patterns of economic activities in residential neighbourhoods in five Dutch cities. Journal of Urban Affairs, 36(4), 742-759.

Foord, J. (2012). The new boomtown? Creative city to tech city in east London. Cities, 33, 521-560.

Frenckel, A., Bendit, E., \& Kaplan, S. (2013). Residential location choice of knowledgeworkers: The role of amenities, workplace and lifestyle. Cities, 35, 33-41.

Gale, C.G., Singleton, A.D., Bates, A.G., \& Longley, P.A. (2016). Creating the 2011 area classification for output areas (2011 OAC). Journal of Spatial Information Science, 12, 127.

Glaeser, E.L. Kerr, S.P., \& Kerr, W.R. (2015). Entrepreneurship and urban growth: an empirical assessment with historical mines. The Review of Economics and Statistics, 97(2), 498-520. 
Glaeser, E.L., Kerr, W.R., \& Ponzetto, G.A.M. (2010b). Clusters of Entrepreneurship. Journal of Urban Economics, 67, 150-168.

Glaeser, E.L., Rosenthal, S.S., \& Strange, W.C. (2010a). Urban economics and entrepreneurship. Journal of Urban Economics, 67, 1-14.

Goldberg-Miller, S.B.D., \& Heimlich, J.E. (2017). Creatives' expectations: The role of supercreatives in cultural district development. Cities, 62, 120-130.

Gornostaeva G. (2008). The film and television industry in London's suburbs: lifestyle of the rich or 'losers' retreat. Creative Industries Journal, 1(1), 47-71.

Gottlieb, P.D. (1995). Residential Amenities, Firm Location and Economic Development. Urban Studies, 32(9), 1413-1436

Grodach, C., Currid-Halkett, E., Foster, N., \& Murdoch, J. (2014). The location patterns of artistic clusters: A metro- and neighborhood-level analysis. Urban Studies, 51(13), 28222843.

Hägerstrand T. (1970). What about people in regional science? Papers of the Regional Science Association, 1(24), 7-21.

Hansen, H.K., \& Niedomysl, T. (2009). Migration of the creative class: evidence from Sweden. Journal of Economic Geography, 9, 191-206.

He, J., Huang, X., \& Xi, G. (2018). Urban amenities for creativity: An analysis of location drivers for photography studios in Nanjing, China. Cities, 74, 310-319.

Heebels, B., \& Van Aalst, I. (2010). Creative clusters in Berlin: entrepreneurship and the quality of place in Prenzlauer Berg and Kreuzberg. Geografiska Annaler: Series B, Human Geography, 92(4), 347-363.

Houston, D., Finlay, A., Harrison, R., \& Mason, C. (2008). Will attracting the "Creative Class" boost economic growth in old industrial regions? A case study of Scotland. Geografiska Annaler Series B Human Geography, 90(2), 133-149.

Hu, L., \& Schneider, R.J. (2017). Different ways to get to the same workplace: How does workplace location relate to commuting by different income groups? Transport Policy, 59(October), 106-115.

Hutton, T.A. (2004). The New Economy of the inner city. Cities, 21(2), 89-108.

Jacobs, J. (1969). The Economy of Cities. New York: Random House.

Johnson, J.D., \& Rasker, R. (1995). The Role of Economic and Quality of Life Values in Rural Business Location. Journal of Rural Studies, 11(4), 405-416.

Kane, K., \& Clark, W.A.V. (2019). Mapping the landscape of urban work: Home-based businesses and the built environment. Environment and Planning A, 51(2), 323-350.

Larsson, J.P. (2017). Non-routine activities and the within-city geography of jobs. Urban Studies, 54(8) 1808-1833.

Larsson, J.P., Wennberg, K., Wiklund, J., \& Wright, M. (2017). Location choices of graduate entrepreneurs. Research Policy, 46, 1490-1504.

Lawton P, Murphy E., \& Redmond D (2013). Residential preferences of the creative class? Cities, 31, 47-56.

Lee, Y.S. (2017). Entrepreneurship, small businesses and economic growth in cities. Journal of Economic Geography, 17, 311-343.

Lee, Y.S., Florida, R., \& Acs, Z. (2004). Creativity and Entrepreneurship: A Regional Analysis of New Firm Formation. Regional Studies, 38(8), 879-891.

Li, L., \& Wu, X. (2014). House Prices and Entrepreneurship in China. Journal of Comparative Economics, 42, 436-449.

Love, L.L., \& Crompton, J.L. (1999). The Role of Quality of Life in Business (Re)Location Decisions. Journal of Business Research, 44, 211-222.

Lynch, P.A. (2005). The commercial home enterprise and host: a United Kingdom perspective. International Journal of Hospitality Management, 24(4), 533-553. 
Markusen, A. (2006). Urban development and the politics of a creative class: evidence from a study of artists. Environment and Planning A, 38, 921-1940.

Marshall, A. (1925). Principles of Economics. 8th ed. London: Macmillan.

Mason, C.M., Carter, S., \& Tagg, S. (2011). Invisible Businesses: The Characteristics of Home-based Businesses in the United Kingdom. Regional Studies, 45(5), 625-639.

May, W., Mason, C., \& Pinch, S. (2001). Explaining industrial agglomeration: The case of the British high-fidelity industry. Geoforum, 32(3), 363-376.

McCann, P. (2008). Globalization and economic geography: the world is curved, not flat. Cambridge Journal of Regions, Economy and Society, 1(3), 351-370.

Michelacci, C., \& Silva, O. (2007). Why so many local entrepreneurs? The Review of Economics and Statistics, 89(4), 615-633.

Miguélez, E., \& Moreno, R. (2014). What attracts knowledge workers? The role of space and social networks. Journal of Regional Science, 54(1), 33-60.

Moos, M.L. (1997). Reinventing the central city as a place to live and work. Housing Policy Debate, 8(2), 471-490.

Muth, R.F. (1969). Cities and Housing. Chicago: Chicago University Press.

Nemes, S., Jonasson, J.M., Genell, A., \& Steineck, G. (2009) Bias in odds ratios by logistic regression modelling and sample size. BMC Medical Research Methodology, 9(56) doi:10.1186/1471-2288-9-56

ONS - Office for National Statistics (2015). Business Demography, UK: 2014. ONS

Pallares-Barbera, M., Tulla, A.F., \& Vera, A. (2004) Spatial loyalty and territorial embeddedness in the multi-sector clustering of the Berguedà region in Catalonia (Spain). Geoforum, 35, 635-649.

Parker, S.C. (2004). The Economics of Self-employment and Entrepreneurship. Cambridge et al.: Cambridge University Press.

Peduzzi, P., Concato, J., Kemper, E., Holford, T.R., \& Feinstein, A.R. (1996). A Simulation Study of the Number of Events per Variable in Logistic Regression Analysis. Journal of Clinical Epidemiology, 49: 1373-1379.

Phe, H.H., \& Wakely, P. (2000). Status, Quality and the Other Trade-off: Towards a New Theory of Urban Residential Location. Urban Studies, 37(1), 7-35.

Phelps, N.A. (2012). The sub-creative economy of the suburbs in question. International Journal of Cultural Studies, 15(3) 259-271.

Rosenthal, S.S., \& Strange, W.C. (2009). Small establishments/big effects: agglomeration, industrial organization, and entrepreneurship. In: Glaeser, E.L. (Ed.), Agglomeration Economics (pp. 277-302). Chicago: University of Chicago Press.

Sánchez-Moral S, Arellano A., \& Díez-Pisonero R (2018). Interregional mobility of talent in Spain: The role of job opportunities and qualities of places during the recent economic crisis. Environment and Planning A, 50(4), 789-808.

Scott, A.J. (2011). Emerging cities of the third wave. Cities, 15(3-4), 289-321.

Shearmur, R. (2006). Travel From Home: An Economic Geography of Commuting Distances in Montreal. Urban Geography, 27(4), 330-359.

Shearmur, R. (2009). Who's your city? How the creative economy is making where you live the most important decision of your life by Richard Florida. Canadian Geographer, 53(3), 379-381.

Smith, B., \& Olaru, D. (2013). Lifecycle stages and residential location choice in the presence of latent preference heterogeneity. Environment and Planning A, 45, 2495-2514.

Storper, M., \& Venables, A.J. (2004). Buzz: Face-to-face contact and the urban economy. Journal of Economic Geography, 4, 351-370.

Tabachnick, B.G., \& Fidell, L.S. (2014). Using Multivariate Statistics. 6th edition. Harlow: Pearson. 
Van Ommeren, J.N., \& van der Straaten, J.W. (2008). The effect of search imperfections on commuting behaviour: Evidence from employed and self-employed workers. Regional Science and Urban Economics, 38(2), 127-147.

Van Oort, F.G., Weterings, A., \& Verlinde, H. (2003). Residential Amenities of Knowledge Workers and the Location of ICT-Firms in the Netherlands. Tijdschrift voor Economische en Sociale Geografie, 94(4), 516-523.

Vittinghof, E., \& McCulloch, C.E. (2006). Relaxing the Rule of Ten Events per Variable in Logistic and Cox Regression. American Journal of Epidemiology, 165, 710-718.

Vorley, T., \& Rogders, P. (2012). Home is where the business is: Incidents in everyday life and the formation of home-based businesses. International Small Business Journal, 32(4), $428-448$.

Wenting, R., Atzema, O., \& Frenken, K. (2011). Urban Amenities and Agglomeration Economies? The Locational Behaviour and Economic Success of Dutch Fashion Design Entrepreneurs. Urban Studies, 48(7), 1333-1352.

Yang Liu, C., \& Huang, X. (2016). The Rise of Urban Entrepreneurs in China: Capital Endowments and Entry Dynamics. Growth and Change, 47(1), 32-52. 
Figure 1. Location of the City of Edinburgh

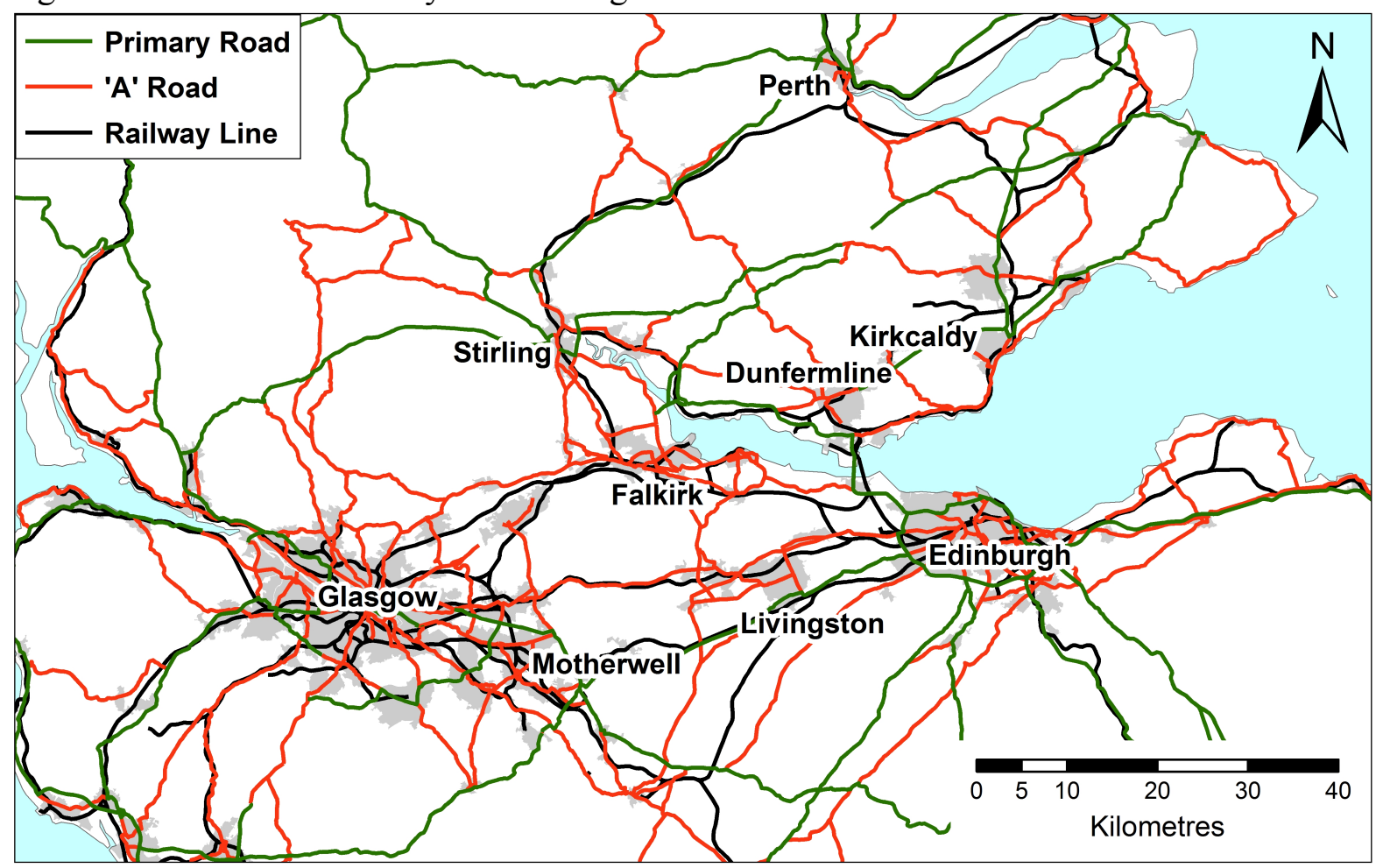

Produced by Paul Carter, University of Portsmouth, using Ordnance Survey Edina Digimap Meridian and Strategi data, including public sector information licensed under the Open Government Licence v3.0. Crown copyright and Database rights 2019 Ordnance Survey (100025252). 
Figure 2. Neighborhood types and central zone in the City of Edinburgh

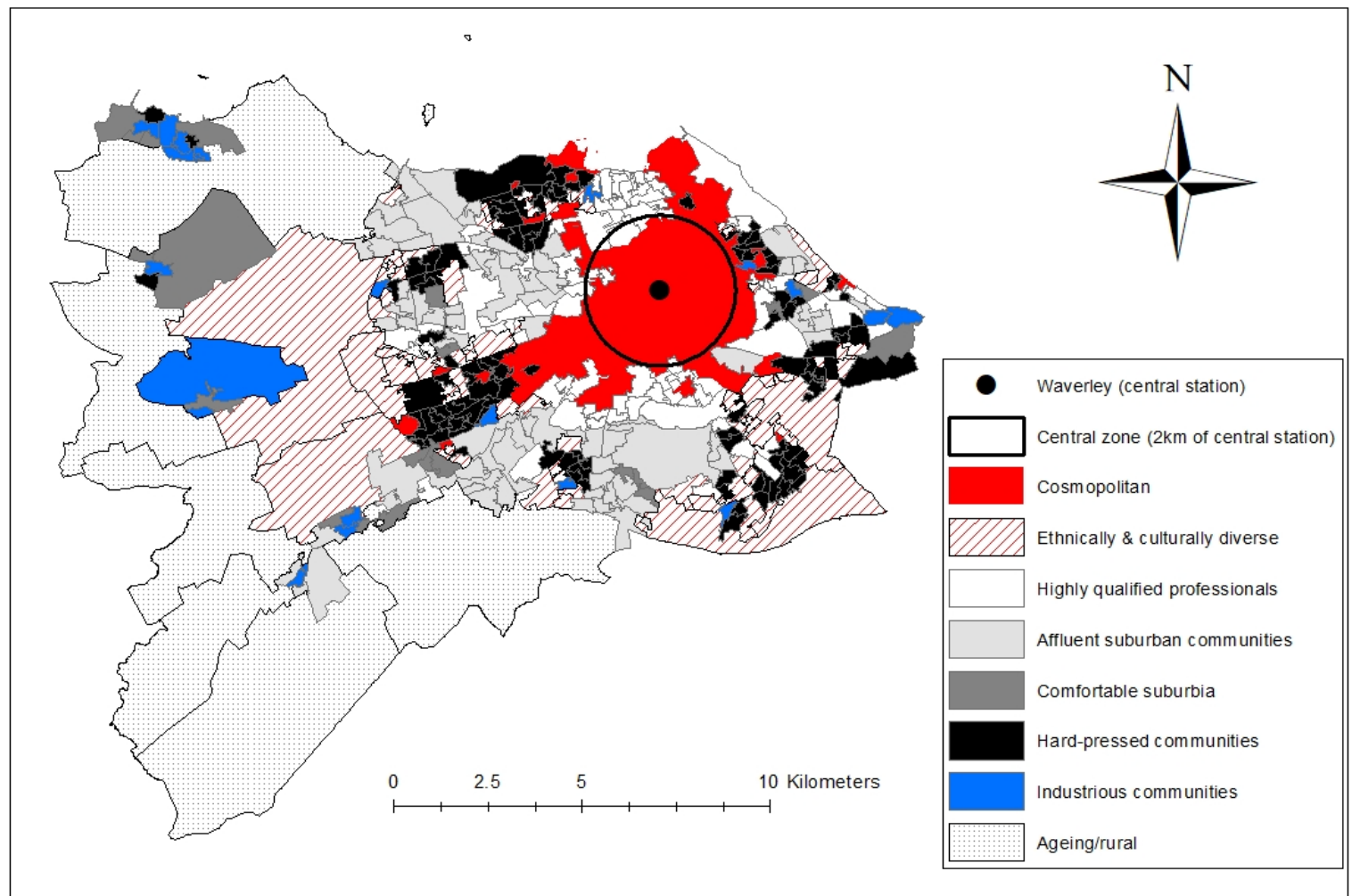

Produced by the authors using Office for National Statistics' 2011 Area Classifications for Super Output Areas (Data Zones in Scotland), matched to digital Census boundaries accessed from the UK Data Service. Copyright 2018 UK Data Service. 
Table 1. Sample and variable description

\begin{tabular}{|c|c|c|c|c|}
\hline Variables & mean & minimum & maximum & $\mathbf{n}$ \\
\hline \multicolumn{5}{|l|}{ Entrepreneurial business } \\
\hline Motivated by opportunity & 0.49 & 0 & 1 & 151 \\
\hline Business startup ( $<24$ months) & 0.11 & 0 & 1 & 149 \\
\hline Opportunity-driven or startup & 0.52 & 0 & 1 & 151 \\
\hline $\begin{array}{l}\text { Necessity-motivated (could not find } \\
\text { adequate job/redundancy) }\end{array}$ & 0.16 & 0 & 1 & 151 \\
\hline Age of business (years) & 12.21 & 0 & 43 & 149 \\
\hline \multicolumn{5}{|l|}{ Type of business premises } \\
\hline Home as premises & 0.32 & 0 & 1 & 153 \\
\hline Home as base/no fixed workplace & 0.15 & 0 & 1 & 153 \\
\hline Commercial premises & 0.53 & 0 & 1 & 153 \\
\hline Commuting distance $(\mathrm{km})^{1}$ & 7.94 & 0.07 & 67.24 & 80 \\
\hline \multicolumn{5}{|l|}{ Legal status } \\
\hline Sole proprietor & 0.25 & 0 & 1 & 151 \\
\hline Limited liability company & 0.63 & 0 & 1 & 151 \\
\hline Limited liability partnership & 0.07 & 0 & 1 & 151 \\
\hline Other partnership & 0.03 & 0 & 1 & 151 \\
\hline Number of employees in business & 2.30 & 0 & 9 & 153 \\
\hline \multicolumn{5}{|l|}{ Industry } \\
\hline Manufacturing incl. transport & 0.07 & 0 & 1 & 153 \\
\hline Wholesale, retail & 0.10 & 0 & 1 & 153 \\
\hline Accommodation and food services & 0.10 & 0 & 1 & 153 \\
\hline Information and communication & 0.05 & 0 & 1 & 153 \\
\hline Financial, insurance \& real estate & 0.16 & 0 & 1 & 153 \\
\hline Profess., scientific, technical services & 0.24 & 0 & 1 & 153 \\
\hline Administrative and support services & 0.05 & 0 & 1 & 153 \\
\hline Education & 0.07 & 0 & 1 & 153 \\
\hline Health and social work & 0.08 & 0 & 1 & 153 \\
\hline Other services, incl. arts & 0.07 & 0 & 1 & 153 \\
\hline Knowledge-intensive industry activity & 0.58 & 0 & 1 & 153 \\
\hline Woman & 0.24 & 0 & 1 & 151 \\
\hline Man & 0.76 & 0 & 1 & 151 \\
\hline \multicolumn{5}{|l|}{ Age of business owner } \\
\hline $25-39$ & 0.18 & 0 & 1 & 151 \\
\hline $40-49$ & 0.25 & 0 & 1 & 151 \\
\hline $50+$ & 0.57 & 0 & 1 & 151 \\
\hline Lives with dependent child & 0.52 & 0 & 1 & 151 \\
\hline
\end{tabular}

${ }^{1}$ Excluding business owners who are home-based or have no fixed business location.

Source: Authors' survey of small business owners in Edinburgh, 2013/14 
Table 2. Residential location by neighborhood types of sample of business owners and all workers in Edinburgh, column percentages

\begin{tabular}{lcccc}
\hline Neighborhood type of residential location & All workers & \multicolumn{3}{c}{ Sample of business owners } \\
& & All & $\begin{array}{c}\text { Entre- } \\
\text { preneurial }\end{array}$ & $\begin{array}{c}\text { Not entre- } \\
\text { preneurial }\end{array}$ \\
\hline Cosmopolitan & 29.5 & 39.7 & 50.0 & 28.8 \\
Highly qualified professionals & 9.0 & 15.8 & 9.0 & 22.7 \\
Ethnically and culturally diverse & 8.9 & 7.5 & 3.8 & 12.1 \\
Hard-pressed communities & 18.4 & 2.1 & - & 4.6 \\
Industrious communities & 10.9 & 6.2 & 6.4 & 6.1 \\
Affluent suburban communities & 8.8 & 19.9 & 20.5 & 18.2 \\
Comfortable suburbia & 7.0 & 2.7 & 3.9 & $*$ \\
Aging/rural & 7.4 & 6.2 & 6.4 & 6.1 \\
Total & 100 & 100 & 100 & $(99)$ \\
\hline Notal &
\end{tabular}

Note: $N=307,157$ workers in Edinburgh and $n=146$ business owners with businesses located in

Edinburgh (column 'all'). Of those $n=78$ are classified as entrepreneurial and $n=66$ as not entrepreneurial (two cannot be classified).

*Less than three observations.

Source: 2011 Area Classification for Data Zones (all workers) and authors' Edinburgh Small Business Survey 2013/2014

Table 3. Workplace location by neighborhood type of sample of business owners and all workers with workplaces in Edinburgh, column percentages

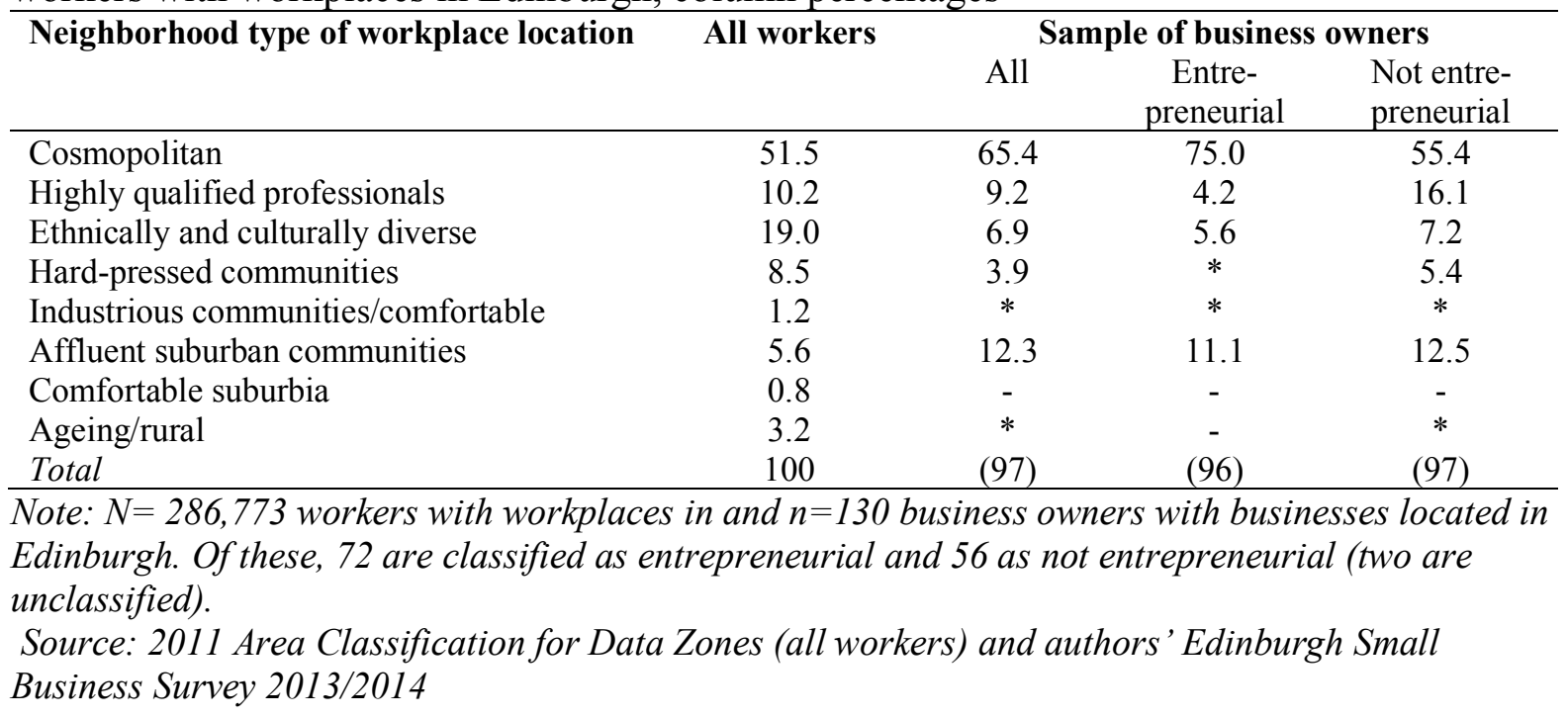


Table 4. Spatial location of residence and workplace, business owners and all workers with a workplace in Edinburgh, percentage shares

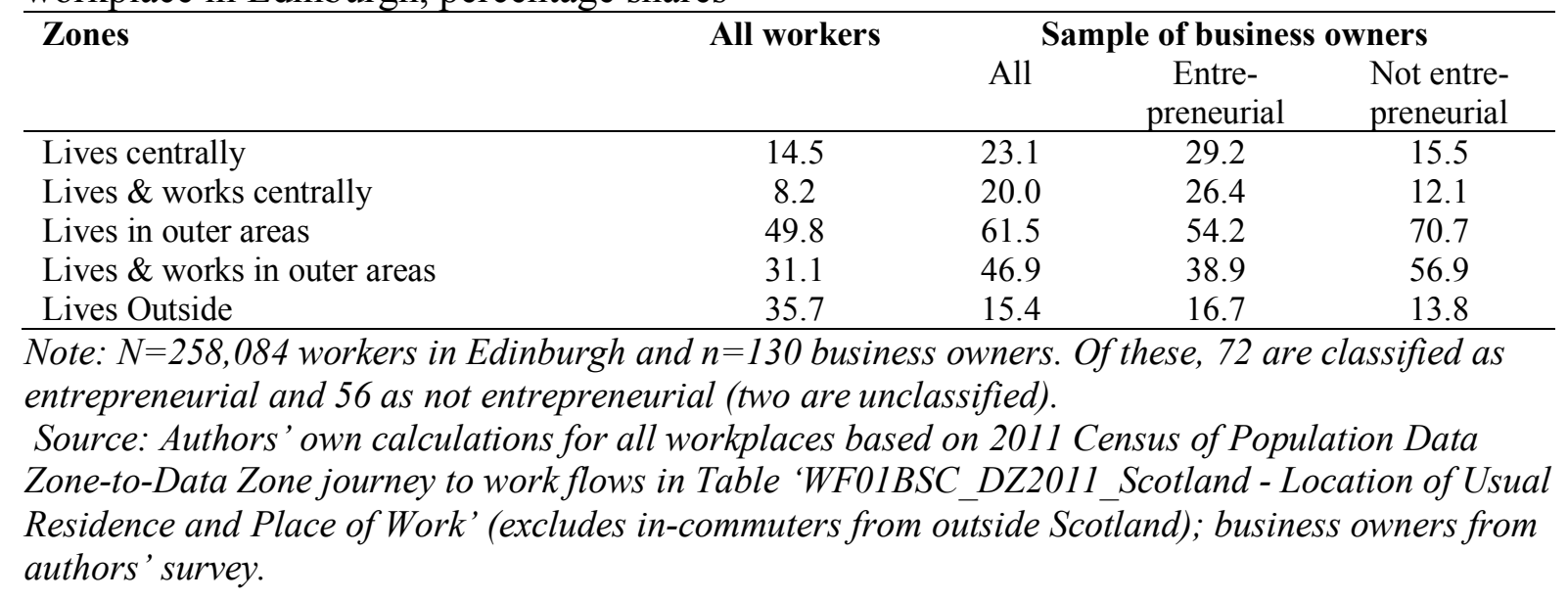

Table 5. Prevalence of commuting distances among business owners and all workers with a commute (percent and cumulative), workplace destinations in the City of Edinburgh

\begin{tabular}{|c|c|c|c|c|c|c|c|c|}
\hline \multirow[t]{3}{*}{ Distance } & \multicolumn{6}{|c|}{ Sample of business owners } & \multicolumn{2}{|c|}{ All workers } \\
\hline & \multicolumn{2}{|c|}{ All } & \multicolumn{2}{|c|}{ Entrepreneurial } & \multicolumn{2}{|c|}{ Non-entrepreneurial } & \multirow[b]{2}{*}{ Percent } & \multirow[b]{2}{*}{ Cum. } \\
\hline & Percent & Cum. & Percent & Cum. & Percent & Cum. & & \\
\hline$<1 \mathrm{~km}$ & 18.8 & 18.8 & 12.2 & 12.2 & 25.6 & 25.6 & 6.4 & 6.4 \\
\hline $1-<2 \mathrm{~km}$ & 17.5 & 36.3 & 24.4 & 36.6 & 10.3 & 35.9 & 13.2 & 19.6 \\
\hline $2-<3 \mathrm{~km}$ & 12.5 & 48.8 & 12.2 & 48.8 & 12.8 & 48.7 & 12.5 & 32.1 \\
\hline $3-<5 \mathrm{~km}$ & 18.7 & 67.5 & 19.4 & 68.2 & 18.0 & 66.7 & 17.6 & 49.7 \\
\hline $5-<10 \mathrm{~km}$ & 10.0 & 77.5 & 5.0 & 73.2 & 15.4 & 82.1 & 17.8 & 67.5 \\
\hline $10-<20 \mathrm{~km}$ & 7.5 & 85.0 & 9.7 & 82.9 & 5.1 & 87.2 & 15.3 & 82.8 \\
\hline $20-<30 \mathrm{~km}$ & 8.7 & 93.7 & 9.7 & 92.6 & 7.7 & 94.9 & 7.0 & 89.8 \\
\hline $30+\mathrm{km}$ & 6.3 & 100.0 & 7.4 & 100.0 & 5.1 & 100.0 & 10.2 & 100.0 \\
\hline
\end{tabular}

Note: $N=97,199$ workers with workplaces in the same areas in Edinburgh as the sample of business owners with commutes to business premises $(n=80)$, thereof $n=41$ are entrepreneurial and $n=39$ nonentrepreneurial.

Source: Authors' survey data of business owners and 'all workers' distances calculated from the 2011 Census of Population. The same 115 Census Data Zones were used as workplace destinations for all workers in which the business owners' businesses were located. 
Table 6. Lives in cosmopolitan neighborhood, Odds Ratios, 95\% confidence interval in brackets

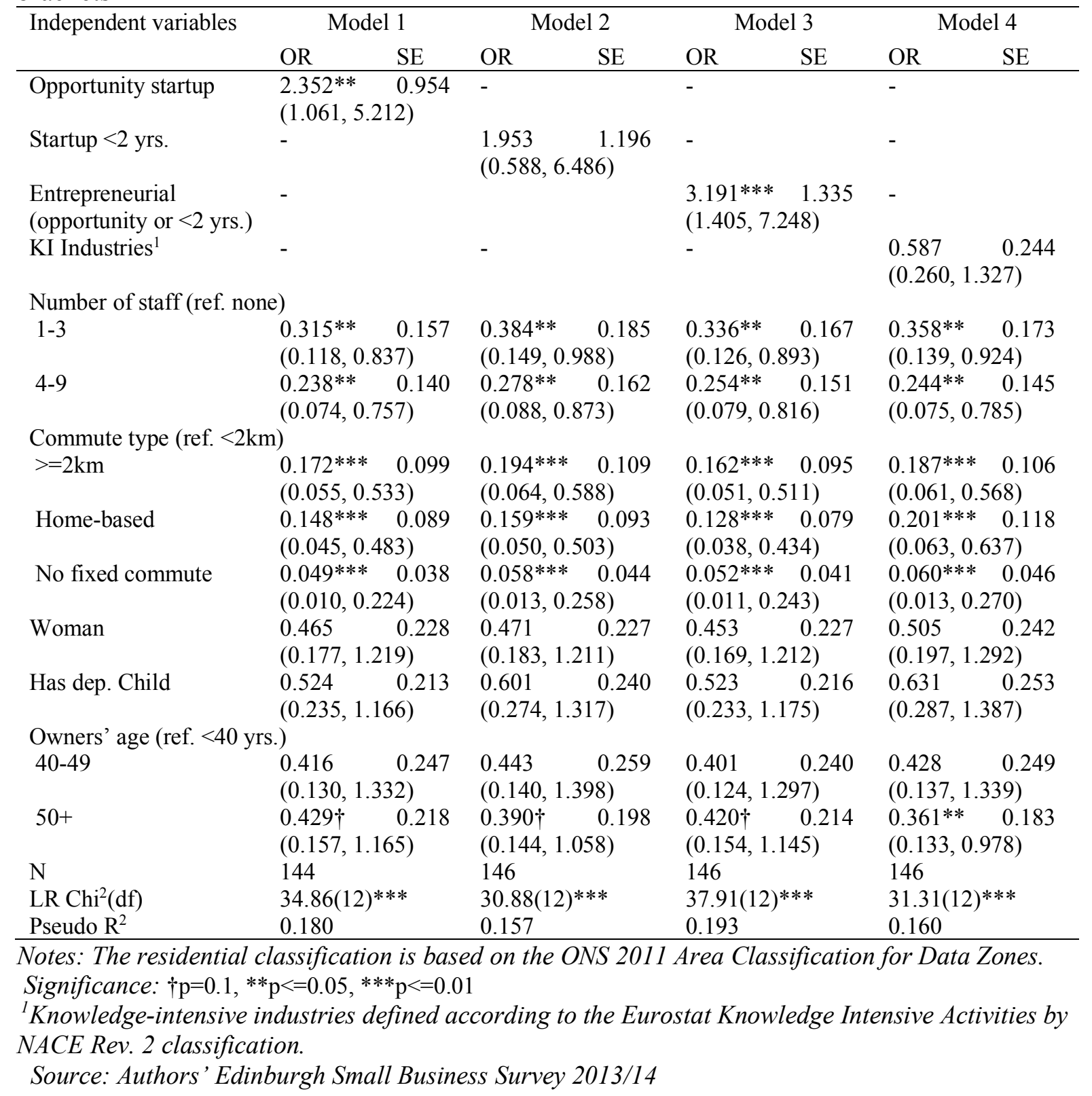


Table 7. Works in cosmopolitan neighborhood, Odds Ratios, $95 \%$ confidence interval in brackets

\begin{tabular}{|c|c|c|c|c|c|c|c|c|}
\hline \multirow[t]{2}{*}{ Independent variables } & \multicolumn{2}{|c|}{ Model 1} & \multicolumn{2}{|c|}{ Model 2} & \multicolumn{2}{|c|}{ Model 3} & \multicolumn{2}{|c|}{ Model 4} \\
\hline & OR & SE & OR & SE & OR & SE & OR & $\mathrm{SE}$ \\
\hline Opportunity startup & \multicolumn{2}{|c|}{$(1.114,5.744)$} & \multicolumn{2}{|c|}{$(1.102,5.634)$} & - & & \multicolumn{2}{|l|}{-} \\
\hline \multirow{2}{*}{$\begin{array}{l}\text { Entrepreneurial } \\
\text { (opportunity or }<2 \text { yrs.) } \\
\text { KI Industries }^{1}\end{array}$} & \multicolumn{4}{|l|}{-} & $\begin{array}{l}3.718^{*} \\
(1.601\end{array}$ & $\begin{array}{l}1.597 \\
32)\end{array}$ & \multicolumn{2}{|c|}{$\begin{array}{l}3.644 * * * \quad 1.555 \\
(1.578,8.413)\end{array}$} \\
\hline & \multicolumn{2}{|l|}{-} & \multicolumn{4}{|c|}{$(0.395,2.150)$} & \multicolumn{2}{|c|}{$(0.406,2.252)$} \\
\hline \multicolumn{9}{|c|}{ Number of staff (ref. none) } \\
\hline $1-3$ & \multicolumn{2}{|c|}{$(0.270,1.869)$} & \multicolumn{2}{|c|}{$(0.262,1.801)$} & \multicolumn{2}{|c|}{$(0.295,2.045)$} & \multicolumn{2}{|c|}{$(0.286,1.967)$} \\
\hline $4-9$ & $\begin{array}{l}1.762 \\
(0.530,5\end{array}$ & $\begin{array}{l}1.080 \\
61)\end{array}$ & $\begin{array}{l}1.621 \\
(0.492,\end{array}$ & $\begin{array}{l}0.985 \\
4)\end{array}$ & $\begin{array}{l}2.140 \\
(0.628\end{array}$ & $\begin{array}{l}1.338 \\
91)\end{array}$ & $\begin{array}{l}1.962 \\
(0.585\end{array}$ & $\begin{array}{l}1.211 \\
79)\end{array}$ \\
\hline \multicolumn{9}{|c|}{ Commute type $($ ref. $<2 \mathrm{~km})$} \\
\hline$>=2 \mathrm{~km}$ & $\begin{array}{l}0.522 \\
(0.157,1 .\end{array}$ & $\begin{array}{l}0.319 \\
30)\end{array}$ & $\begin{array}{l}0.550 \\
(0.168\end{array}$ & $\begin{array}{l}0.331 \\
4)\end{array}$ & $\begin{array}{l}0.490 \\
(0.146\end{array}$ & $\begin{array}{l}0.301 \\
38)\end{array}$ & $\begin{array}{l}0.513 \\
(0.156,\end{array}$ & $\begin{array}{l}0.312 \\
90)\end{array}$ \\
\hline Home-based & \multicolumn{2}{|c|}{$(0.065,0.658)$} & \multicolumn{2}{|c|}{$(0.070,0.726)$} & \multicolumn{2}{|c|}{$(0.055,0.597)$} & \multicolumn{2}{|c|}{$(0.059,0.654)$} \\
\hline Woman & \multicolumn{2}{|c|}{$(0.428,2.686)$} & \multicolumn{2}{|l|}{-} & \multicolumn{2}{|c|}{$(0.435,2.830)$} & - & \\
\hline \multicolumn{9}{|c|}{ Owners' age (ref. $<40$ yrs.) } \\
\hline $40-49$ & $\begin{array}{l}0.730 \\
(0.218,2 .\end{array}$ & $\begin{array}{l}0.449 \\
39)\end{array}$ & $\begin{array}{l}0.726 \\
(0.219\end{array}$ & $\begin{array}{l}0.443 \\
1)\end{array}$ & $\begin{array}{l}0.719 \\
(0.213\end{array}$ & $\begin{array}{l}0.446 \\
29)\end{array}$ & $\begin{array}{l}0.713 \\
(0.213\end{array}$ & $\begin{array}{l}0.439 \\
84)\end{array}$ \\
\hline $50+$ & $\begin{array}{l}1.161 \\
(0.398,3 .\end{array}$ & $\begin{array}{l}0.634 \\
88)\end{array}$ & $\begin{array}{l}1.079 \\
(0.375\end{array}$ & $\begin{array}{l}0.581 \\
4)\end{array}$ & $\begin{array}{l}1.192 \\
(0.405,\end{array}$ & $\begin{array}{l}0.656 \\
08)\end{array}$ & $\begin{array}{l}1.103 \\
(0.381,\end{array}$ & $\begin{array}{l}0.597 \\
91)\end{array}$ \\
\hline $\mathrm{N}$ & 127 & & 127 & & 129 & & 129 & \\
\hline $\mathrm{LR} \mathrm{Chi}^{2}(\mathrm{df})$ & $17.83(9) *$ & & $16.87^{*}$ & & 23.47( & & $22.46(8$ & \\
\hline Pseudo $\mathrm{R}^{2}$ & 0.110 & & 0.104 & & 0.141 & & 0.135 & \\
\hline
\end{tabular}

Notes: The residential classification is based on ONS 2011 Area Classification for Data Zones.

Significance: $\uparrow \mathrm{p}=0.1, * * \mathrm{p}<=0.05, * * * \mathrm{p}<=0.01$

${ }^{1}$ Knowledge-intensive industries defined according to the Eurostat Knowledge Intensive Activities by

NACE Rev. 2 classification.

Source: Authors' Edinburgh Small Business Survey 2013/14

\footnotetext{
i National Records of Scotland, Scotland's Census 2011 Table KS204SC.

ii These figures only include registered businesses.

iii ONS Mid-year population estimate.

iv It is estimated that three-quarters of all UK enterprises in 2015 were one-person businesses and that the majority of these were unregistered businesses (56\%) and/or home-based (59\%)
} (BIS, 2016).

v ONS Inter Departmental Business Register. 
${ }^{\text {vi }}$ Businesses were not included if information on the number of employees was missing and when information on either the residential or business location was incomplete or not within the sampling framework.

vii ONS UK Standard Industrial Classification 2007

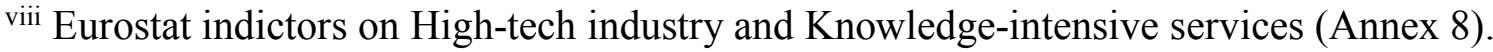

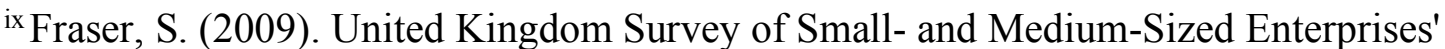
Finances, 2008. [data collection]. UK Data Service. SN: 6314, http://doi.org/10.5255/UKDASN-6314-1

x 'Data Zones' in Scotland are similar in spatial scale and definition to 'Super Output Areas' in the rest of the UK.

${ }^{x i}$ Variables that were used to derive neighborhood types are published in Gale et al. (2016). However, information about the precise composition of each neighborhood type is not available.

xii Where appropriate, we follow ONS's eight 'Super Groups' with the following alterations: i) 'Cosmopolitan student neighbourhoods' and 'Inner city cosmopolitan' combined to form 'Cosmopolitan'; ii) 'Multicultural living' and 'Ethnically diverse professionals' combined to form 'Ethnically and culturally diverse neighbourhoods'; iii) the following Groups are reported as distinct categories rather than being aggregated within their larger 'Super Group' - 'Highly qualified professionals', 'Affluent communities' (which we rename 'Affluent suburban communities' to reflect its Super Group) and 'Comfortable suburbia'; and iv) the 'Ageing suburbia' Group is added to the 'Countryside Living' Super Group and renamed 'Ageing/rural'.

xiii As well as being dominated by 'cosmopolitan' neighbourhoods, the zone we define as central Edinburgh (within $2 \mathrm{~km}$ of the central railway station) represents the city's highdensity core, thus captures an important spatial structure of the city in relation to 
conventional urban models of residential choice. Population density drops by 35 persons per ha (from 81 to 46 ) between the $1-2 \mathrm{~km}$ and $2-3 \mathrm{~km}$ rings, by far the greatest single drop in population density moving out from the city centre.

xiv This approach also conforms with sample size rules of thumb suggested by Tabachnick and Fidell $(2014,159)$.

${ }^{\mathrm{xv}}$ We define Central Edinburgh as all Census Data Zones with their centre falling within a $2 \mathrm{~km}$ buffer of the city's main railway station on Waverly Bridge, which lies at the heart of the central business district. Outer Edinburgh is defined as the area between the central zone and the city's administrative boundary. Beyond the City of Edinburgh administrative boundary lies our final zone, 'outside Edinburgh'. See also endnote xiii.

${ }^{x v i}$ The level of in-commuting is of a similar magnitude to the $38 \%$ of jobs in the 12 English Local Authority areas with $>100,000$ workplaces plus Aberdeen and Edinburgh in Scotland, Belfast in Northern Ireland and Cardiff in Wales (own calculation based on 2011 Census of Population).

xvii Business owners' commute distances were calculated as straight-line distances between the centroids of postcode unit polygons. Postcode units contain an average of 15 addresses each and rarely more than 100. For all workers, we calculated the commutes in the 2011 Census of Population as straight-line distances between the centroids of Census Data Zones. From the Census dataset, 97,199 recorded commutes were extracted originating within Scotland (from residences in a total of 6,976 distinct Data Zones) and ending in one of the 115 Census Data Zones in Edinburgh which contained at least one business address from the present business survey (Table WF01BSC_DZ2011_Scotland).

xviii Commuting distances to workplaces in Edinburgh are in line with comparable cities. The average commute distance of workers with workplaces in Edinburgh is $11.6 \mathrm{~km}$. The average commute to workplaces in similar-sized cities in England plus Aberdeen and Edinburgh in 
Scotland, Belfast in Northern Ireland and Cardiff in Wales is $12.5 \mathrm{~km}$ (own calculation based on Census of Population 2011 Table WP702EW and Table LC7102SC from the Scottish Census).

xix Probability $=$ elogit $/(1+$ elogit $)$

xx Standard Industrial Classification (SIC) codes K, L and M combined. 